\title{
ART, AGENCY AND POWER EFFECTS IN EASt TIMOR: PROVOCATIONS
}

Kelly Silva ${ }^{1}$ e Lúcio Sousa ${ }^{2}$

Universidade de Brasília, Brasil / Universidade Aberta, Portugal

\begin{abstract}
The connection between art, agency and power effects in East Timor is an epistemological equation that entails interdisciplinary approaches. Departing from an anthropological perspective, this introduction seeks to map potential methodological and theoretical questions for discussing such equation. One also outlines registers and historical and contemporary genealogies of artistic practices in order to suggest clues and challenges to be pursued by further studies in the area. The analysis of the articles which this dossier is made up of allows to discuss the development of political appropriation of art by various actors, revealing the emergence of new orientalisms and mediation processes, both local and international, in the making of art worlds in East Timor.
\end{abstract}

Keywords: art, agency, power, East Timor

This dossier aims at opening a space for multidisciplinary analysis and consideration of art production in and about East Timor. Nevertheless, the fact of being conceived by two anthropologists leaves its trace. In this essay, as an introductory provocation to readers interested in this topic, we raise a few theoretical and methodological questions for a critical outlook of art in and about East Timor, from the anthropological point of view. We discuss possible perspectives to approach the art worlds in and about East Timor, by connecting them, as far as possible, to the articles that comprise this dossier. ${ }^{3}$

1 Departamento de Antropologia/Laboratório de Estudos da Globalização e do Desenvolvimento (LEG), Pesquisadora Produtividade em Pesquisa - CNPq. Email:kellysa@pq.cnpq.br

2 Departamento de Ciências Sociais e de Gestão, Centro de Estudos das Migrações e Relações Interculturais. Email: Lucio.Sousa@uab.pt

3 This essay is partially a product of the research line titled Processes of invention, transposition, and subversion of modernity supervised by Kelly Silva at the Department of Anthropology, University of Brasilia. We thank the National Council of Science and Technology $(\mathrm{CNPq})$ of Brazil for funding research which has produced the data of which this essay is a partial product (processes no. 2011-2, 307043/2012-6, 401609/2010-3 e 457845/2014-7). We also thank the National Institute of Studies on Institutional Management of Conflicts (INEAC) for providing additional funds. Our gratitude to David Palazón for his careful reading of a previous draft of this essay, to Alcida 
Anchored in the precept that the emergence of artistic fields (Bourdieu 1983, 1996) is a complex historical process of longue durée, we present some classificatory and institutional mediations in the way they were conceived in Eastern Timor and in other socio-political frontiers. We point out how the invention of art worlds relates to processes of invention, transposition, and subversion of modernity. In turn, these processes are intimately linked to the construction of colonial and post-colonial states. Therefore, we stress the dependence of the field of art production on other fields of social action. We bring up some episodes that mark the colonial genealogy of the production of indigenous and popular art in the then Portuguese Timor. We also invite the readers to undertake ethnographies on classificatory and institutional mediations involved in the construction of artistic fields in contemporary East Timor, by referring to actors who have been protagonists in these processes.

In addition, we explore the analytic potential of an agentive perspective, as conceived by Alfred Gell (1988), for the examination of what we may see as East-Timorese artistic manifestations from the interethnic point of view ${ }^{4}$. We shall take as an exemplary case the issue of semantic parallelism (Fox 1988), a feature of ritual poetry in East Indonesia. We shall also briefly refer to the centrality of the idea of reproduction - as opposed to invention - as a structuring value in some artistic production among local populations. Inspired by the issue of agency, we will show some ways in which the construction of East Timorese art was and still is related to the emergence of a tourist market, in both colonial and post-colonial periods, and to the creation of a national narrative to deploy significant items of tradition, custom or kultura. The use of what Viegas (this volume) calls fragments of tradition also serves to produce new Orientalisms, as well as a project for national identification.

\section{ReAdjusting the outLook}

To begin with, we need to focus on the way art has been conceived in what we rather crudely call the Western world. We cannot generalize the notion that art is the exclusive object of esthetic contemplation, produced by specialists - the so-called artists - and constitutes an autonomous domain of social action regarding other domains (politics, economy, religion, etc.). Rather, it is the result of specific historical processes, among which we underline romanticism, which appeared in Europe (Morphy 2005) between the late 18th and the 19th centuries, and the projects of purification, which set off the construction of Western modernity ${ }^{5}$ (Latour 1994). However, we should not conclude from this that other social collectivities necessarily lack institutions or spaces for esthetic contemplation. What we notice very often is that the ap-

Ramos, for translating it into English and to Hugo Vale, who help us with the editing of images. Due to space limitations, we do not tackle the issue of literary production, which deserves a study in its own right.

4 The lack of a frontier between craft and art, insulation and recognition of certain phenomena characterized as art, among some social collectivities for specific esthetic and semiotic qualities, seems to suggest that their classification as art, from the anthropologist's point of view, is an eminently interethnic phenomenon. We understand interethnic phenomenon as resulting from the intersection of the classification systems of the anthropologist's own society and of the social collectivities with whom he/she works, who may be relatively marginal to the capitalist world.

5 Based on Latour (1994), we understand purification as the processes of and the search for separation through which modern episteme sets ontological frontiers and limits between what is taken as diverse realms, beings and experiences which make up social life, such as the opposition between nature and culture, politics and knowledge, justice and power, humans and non-humans, etc. 
preciation and cultivation of esthetics go together with social actions generally coupled with the making of the person, communication with the ancestors, and reproduction of life (see Layton 2001, Gell 1998, Morphy 2005, Lagrou 2009, among others).

We also deem necessary to suspend the variables that have underscored the recognition of certain cultural expressions as art in the Western world because they have no a priori crosscultural application. Morphy (2005: 651) identifies three large criteria for acknowledging certain phenomena as art in the West: 1) institutional; 2) self-classification; and 3) the object's attributes.

The institutional variable has to do with the recognition of a given cultural expression as art, which will place it in a specific universe of circulation and consumption. In most cases, recognizing something as art in the West has to do with its potential for commodification and incorporation in the art market (Bourdieu 1996), via circulation in museums, galleries, etc. Recognition of certain manifestations as art is a social process made up of mediations of various orders. Among these, we emphasize heritage policies carried out by national states and contemporary transnational government agencies. We shall return to this issue.

Self-classification, in turn, refers to the meaning attributed to a given cultural expression by whoever creates or performs it. Thus, one of the conditions to recognize something as art (among us) is that individuals or collectivities responsible for its existence conceive of it as art. However, most often, this comes with the construction of the artist's name, achieved through multiple mediations in which the anthropologist can also play a role. Hence, certain phenomena may not come into existence as art, but they acquire their status along their biography, its social life. An emblematic example are the Western appropriations of so-called primitive art in which art dealers, art historians, and even anthropologists often take part.

With regard to the attributes of an object, this is usually considered an art piece if its features are outstanding before certain esthetic standards as well as its semantic potential (Lyton 2001: 14). Formerly, the highly specialized technical skills applied to the making of objects recognized as art were also an important variable for that recognition. At that time, the distinction between craft (whose utility was beyond esthetic contemplation) and art was not yet important (Morphy 2005: 649).

Our efforts to objectify (within the limits of this essay) the variables that, from the Western viewpoint, operate as mediators in the construction of the artistic phenomena have a function here. We invite the reader to reflect on the extent to which these phenomena have, or not, been enforced in East Timor in the long run. We argue that the various people who live in the socio-political frontiers that are now part of East Timor have been exposed, both in colonial and post-colonial times, to processes of invention and transposition of modernity. They have also lived through events that have led to the conception and imagination of art as a relatively autonomous field of production and representation, with a number of different effects. The articles in this dossier discuss some episodes related to these processes. In this context, the promotion of development - whatever we may understand it to be - and national construction appear as elements that trigger off art production and invention. These facts seem to indicate, among other things, the dependence of art production on other fields of social action. This trend is far from being unique to East Timor. It corroborates what has happened at other socio-political frontiers. 


\section{From a semiotic to an agentive approach. New overtures for translation and PERCEPTION OF ART IN EAST TIMOR}

The semiotic approach to art has received important criticism (Gell 1998) in anthropology. Among other things, it questions the idea that the artistic phenomenon represents or communicates something that is external to it, and the very notion of representation, for they are not cross-culturally valid. They express but a specific semiotic ideology ${ }^{6}$ (Keane 2007). Based on his research among Papua New Guinea peoples, Gell (1998: 6) suggested that we approach art as an agentive entity that carries intentions and causations and produces results and transformations.

The shift of analytic attention from meaning to efficacy, in Lagrou's (2009:32) terms, can be cognitively valuable in the analysis of occurrences we recognize as artistic (the effect of an interethnic outlook) among East Timorese peoples. We highlight ritual narratives and their typical semantic parallelism (Fox 1988). This phenomenon is characterized as a narrative genre that deploys synonymous words or metaphors, framed as either prose or poetry, in oral, formal, and canonic performances. ${ }^{7}$ In this case, its expressive form and esthetic quality are the main elements of its function and efficacy, as is the control of its knowledge and reproduction. Dance can also reinforce this agentive component (Sousa 2010). In the colonial period, the record of these narratives seemed mostly to favor the esthetic dimension as a constitutive feature of a memory for a future that is now being recovered. The works of Artur de Sá (1961), José Rodrigues (1962), and Ezequiel Pascoal (1967) are, among others, very good examples. In addition, some authors with ethnographic inclination risked ethnological approaches to these narratives, as did Francisco de Azevedo Gomes (1972) in Os Fataluku (The Fataluku) and Jorge Barros Duarte (1984) in Timor Ritos e Mitos Ataúros (Timor Atauro Rites and Myths).

Lagrou (2009: 14, 23, 27) states that contemporary Amerindian peoples do not regard art or artistic production as self-contained entities with value in themselves, but rather as knowledge acquired from mystical beings with power to act upon and transform the world. In similar fashion, ritual oratory in Eastern Indonesia does not originate in itself, nor is it self-contained. Its efficacy derives from its association with the voice of the ancestors, from its connection with a sacredness regime responsible for the creation and reproduction of the world (see the photographic essay by Simião, Rocha and Almeida, this volume). This kind of ritual oral performance has even been included in the representation of the East Timorese nation since the ceremonies of independence restauration in Dili, May 20, 2002. ${ }^{8}$

6 The notion of linguistic ideology as stated by Silverstein (2000) involves a set of beliefs about language expressed by users as rationalization or justification of the language they use. Based on this, the idea of semiotic ideology goes beyond. It affirms that one must first observe what counts or not as language in different cultural landscapes and the meaningful and agentive effects attributed to its various configurations. For Eastern Indonesia, based on his research in Sumba, Keane (2007) provides a series of analyses that show the agentive power of words and things in the negotiation of sociality.

7 As a hypothesis, we propose that at least part of the narratives on street art, as analyzed by Arthur (this volume) has components of semantic parallelism as discussed here. Good examples are the repeated times when the "Paz no dame" mobilizer (Dame being the Tetum term for peace) appears in visual narratives. We also risk proposing that some sort of semantic and complementary parallelism is present in sculpture production among East Timorese peoples.

8 Elsewhere in East Timor, that same night, other performances took place. We might ask whether the reasons of the event organizers and of the ritual speakers were the same. 
The understanding of formal, ritual narratives, as expressed in semantic parallelism, is that they produce truth, thus defining the order and meaning of the world and, hence, reproducing it. The monopoly of certain narrative forms has several power effects. Different peoples conceive this monopoly as a product of collective enterprises in which the living, the dead, and the ancestors participate. ${ }^{9}$ As opposed to the valorization of creativity and innovation that characterize some artistic products in our societies, a good performance of a ritual narrative resides in its similitude to what is seen as its original form. Reproduction and repetition, rather than innovation, are the elements that add value to artistic expression. On this point, what Lagrou (2009: 67) says about the pragmatics of conservation and continuity of Amerindian artistic production leads us to think about a similar trend in East Timor local art:

(...) This valorization of a history of conservation and continuity, in contrast to our valuing of a history of rupture and discontinuity with the past, may relates to a corresponding valorization of non-cumulative art (...) at the service of a certain life style. Hence, the recurring answer to the question about the meaning of a given motif or form: 'this is our custom. ${ }^{10}$

Those who are familiar with ethnographic research in Timor know that the statement 'this is our custom' is also very common among its peoples. In his seminal and forerunner work on Timorese art, Ruy Cinatti (1987: 65) affirms:

Ask a Timorese artisan about certain motifs in the carvings of house rafters at Los Palos, about the most evident patterns in Ocussi cloth (sic) or, etc., at the various Timor places where ornaments are most developed. His invariable answer is that his grandparents already did it in this way, meaning that there is no individual creation, and that he, the artisan, limits himself to interpret the imaginative thinking of his fellow citizens, according to prescribed patterns. (...)

The Timorese artisan is, above all, an intellectual: the creation model is like an intelligible word in his mind; he will give the final touches when leisure permits, for artisanship and the artistic function are not distinguishable from other collective tasks, such as gardening, or house construction. (...) Art without a purpose is a secondary concept, which was thrived by foreign influence (...).

In light of this passage, we hypothesize that the agency to produce what we, outsiders, recognize as art, in rural East Timor, in general, may have more to do with reproduction than with creation skills. Its value would be in replacing a form thought to be ancestral, rather than in the artist's inventive disposition.

Ruy Cinatti's (1987: 65) quote also confirms our initial point. In many socio-political frontiers, art as esthetic contemplation and autonomous field of social action seems to make little sense. The photographic essay by Simião, Rocha and Almeida (this volume) also gives us some clues about this. We can see in it how esthetic work is associated to specific sacredness regimes (Lulik and Catholic) which, nevertheless, are in mutual communication. Symbolic and esthetic expressions are, at the same time, form and medium for religious practice. Based on this essay and on our very research experience in different East Timor contexts, we risk proposing the following. To a certain extent, we can think of many religious experiences in East Timor

9 Fox (1988) defies us to think about the correlations between semantic parallelism and other aspects of local social dynamics, such as complementary classificatory dualism and social organization dynamics. Unlike complementary classificatory dualism, which includes a ranking in the position of its terms, in semantic parallelism this feature is absent (1988: 26). From this observation, Fox challenges us with a very interesting analytical question: "how do non-hierarchical pairs of words are transformed into hierarchical pairs of terms?"

10 All the Portuguese language citations have been translated into English. 
as esthetic contemplation and management, given the compulsory character of its materialization, highly regulated in the form of rituals where words, relics, sacrifices, and gifts have agency, especially in the Lulik universe. Unlike Lulik, Christianity appears as a less materialized cult experience, as Keane (2007) tells us.

Still on the issue of agency, at least three of the texts in this volume give us elements to perceive some consequences of production and reproduction of visual arts in Dili. Arthur, for instance, demonstrates how street art has been both a medium for protest and for political unification, by linking intergenerational language proficiency to the visual expression of its demands. Information and analyses provided by Viegas and Bexley, in turn, show us how the spaces of artistic formation and production in communities such as Arte Moris and Gembel are also spaces for the production of more autonomous subjects and subjectivities, as opposed to expectations of more relational and hierarchical sociability, typical of their primordial institutions of origin (family, houses, etc.). Fidalgo-Castro presents yet another facet of art agency, discussed in his text via processes of state appropriation of sacred houses as cultural heritage in East Timor. In this case, culture, translated as art expressed in sacred house esthetics, rises to the condition of cultural capital and national symbol. Hence, art agency would reside precisely in its potential as the nation's symbol. This case indicates that the agentive and symbolic approaches to art are not necessary exclusive.

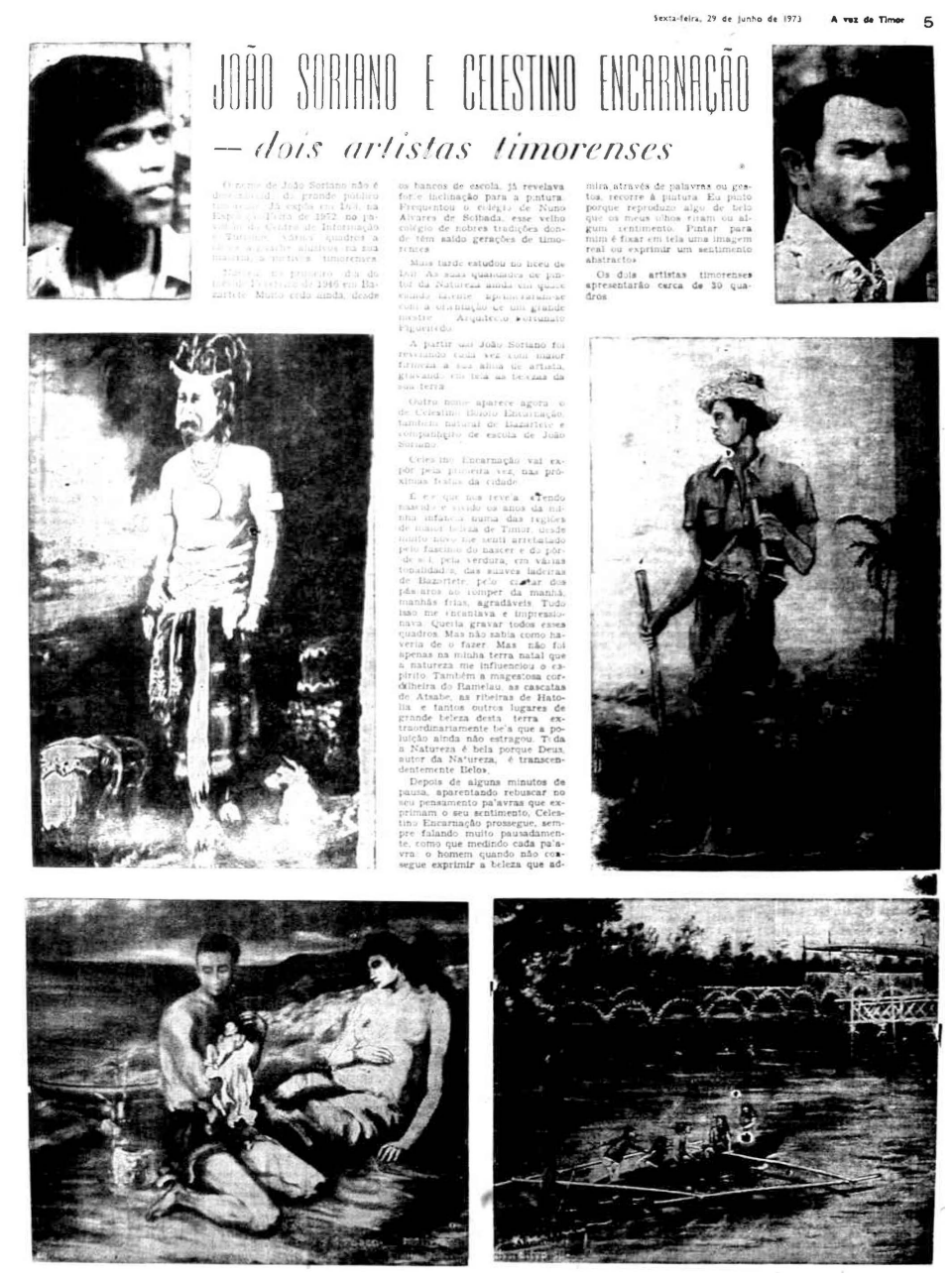

Figure 1 


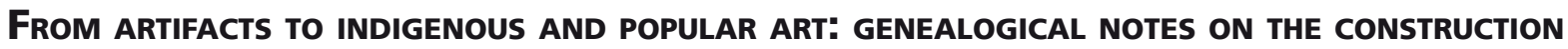 of the arts in Portuguese Timor}

Some 19th century authors perceived beauty in artifacts made by East Timorese peoples as the minimalist production of a people with a "savage expression," but still with taste, ability, and patience. Afonso de Castro, in referring to "textile industry," meaning artisan production, states that it was "very backward," due, according to him, to the Timorese scarce and limited needs. Nevertheless, in female weaving,

(...) the beauty of some of those artifacts, the way they combine colors, and their durability, show us that the 'Timors' are not devoid of ability; if well managed by European entrepreneurs, they could compete with Java inhabitants in making certain products. (Castro 1867: 335)

In 1891, Bento de França, in his booklet Timor, in mentioning the "textile industry" of the "Timors", affirms that:

Those islanders are not clumsy; to the contrary, they have great manual ability, but due to their invincible indolence, they limit their artifacts to the strictly needed. These artifacts are limited to coarse cotton cloth woven by women in crude bamboo looms; silk and cotton fabrics, products in beautiful hues, clay pots and bowls; turtle combs and buffalo sticks, goges (a kind of bag) of all sorts and shapes; carved and arabesque-drawn bamboo straws; boxes, straw baskets and cigarette pouches, and relatively coarse ornamental drawings. In all these products, many of them crude, the 'Timors' reveal a great deal of taste, patience and ability in manual work, despite their savage condition. (França 1891: 40)

In the early 20th century, these local expressions of artisan production acquired a new social life. The Álvaro Fontoura Album, attributed to the Governor of that name, gives a photographic overview of Portuguese Timor in the late 1930s. Among the laudatory listing of peoples and colonizing actions, we find an item dedicated to indigenous art illustrated with images of artifact making and their exhibition at a fair to celebrate the 10th anniversary of the "National Revolution." Goldsmithery, weaving, turtle shell jewelry, and bamboo boxes with anthropomorphic lids representing indigenous and city dwellers, seem to substantiate what is taken as art in the re-creation of a local production basically catered to a metropolitan market; its outlet is a showcase of local products during the annual fair to celebrate Portugal Day on July 10 th. ${ }^{11}$

One of the first ethnological approaches to art was done by António de Almeida (1994 [1959]) in 1959, although he did not distance himself from previous descriptions. In his Notas sobre Artes e Ofícios de nativos de Timor Português (Notes on the Arts and Crafts of the Natives of Portuguese Timor), the author attempts to systematize the field of arts and crafts in Portuguese Timor. He describes the making of salt, pottery, weaving, ropes and plated pieces, decorated brass objects, jewels, buffalo horn sculptures, and houses on the east side of the territory.

Encouragement to transform these goods from artifacts to esthetic objects came from a new demand, be it by city dwellers, or by the new foreigners who poured in Timor in the 1960s, namely, tourists. Francisco Xavier de Menezes (2006 [1968]) explains the influence of foreigners in Timorese artisanship, and the surge of an internal demand to the point that, says the author, it became the object of an institutional incentive by the Centro de Informação e Turismo

11 The Alvaro da Fontoura Album is available online at:http://www.ics.ul.pt/ahsocial/fontoura/album/pag_inteiras/0.htm..Assessed March 3, 2015. 
(Center of Information and Tourism) and the Casa de Timor (Timor House).

A wider recognition of Timorese art appears in an article by Luís Filipe Thomaz published in 1968/1975. Titled Arte Popular (Popular Art), it is dedicated to the territory, and is part of a volume on Popular Art in Portugal, Adjoining Islands and Overseas. He divides art into decorative arts, predominant in Timor, and greater art (stone architecture, sculpture, and painting). He lists and highlights architecture, shipbuilding, sculpture, turtle works, bamboo works, weaving, lace and various embroidery techniques, including sieve embroidery (strongly influenced by colonization, especially missionary), basketry, pottery, goldsmith work, metallurgy, carpentry, music, and dance. The author states that in certain regions, administrative authorities tried to develop wood sculpture "to imitate Balinese models," which resulted in “(...) an unspontaneous art, much inferior to that they intended to imitate" (Thomaz, 2008[1968-1975]).

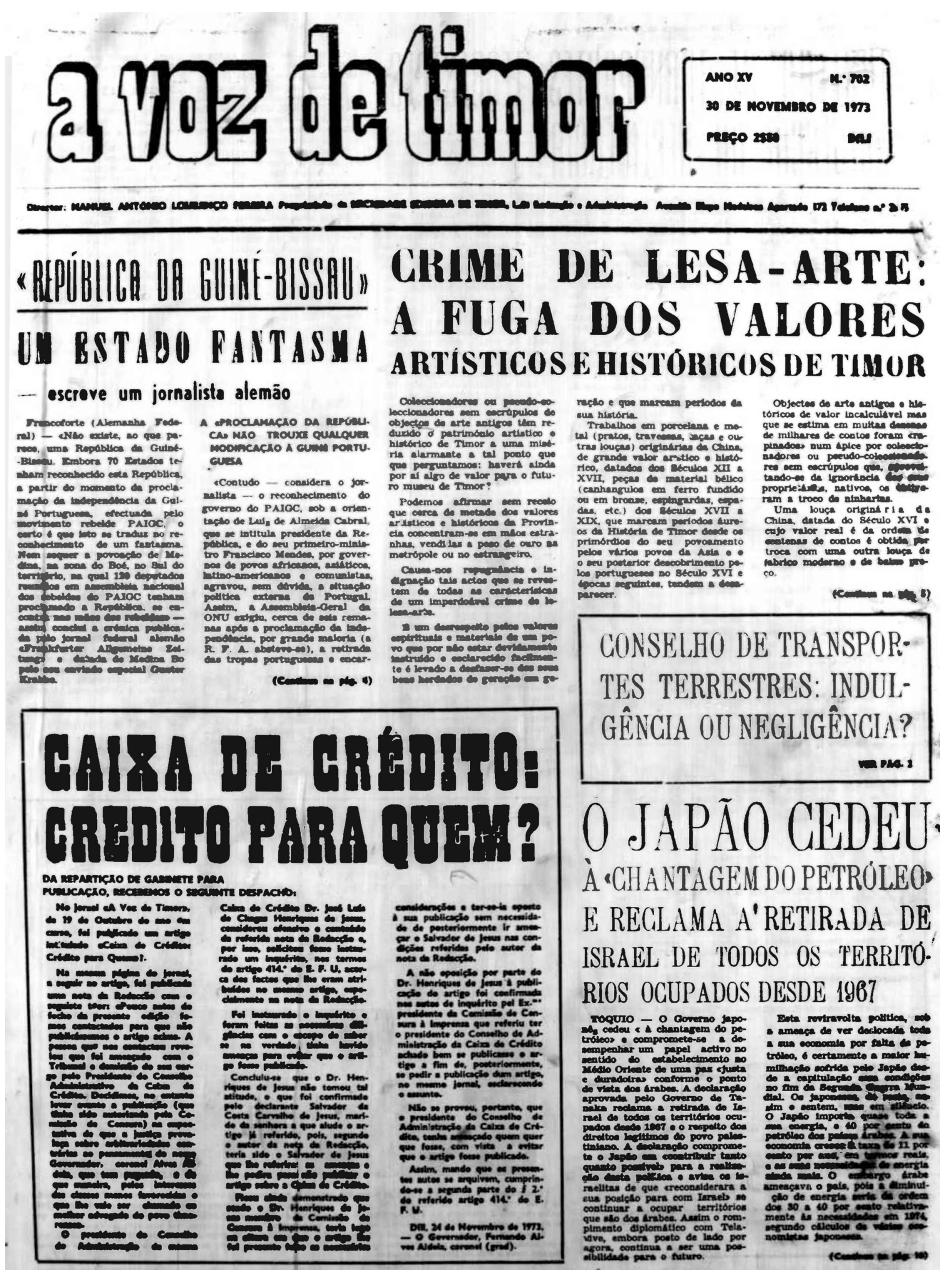

Figure 2

Ruy Cinatti (1987) also mentions mimetism and artifact making based on an external demand. As he comments, much of the art exhibited at A Casa de Timor (The Timor House) had an official inspiration fostered by local managers who sponsored production. However, Cinatti is equally critical of the emptying out, the adulteration of Timorese art in this process. He considers it to be "geared toward the destruction of Timorese cultural values" $(1987,16)$, which may lead to the extinction of stylistic, motif and technical patterns. The purpose of his book Motivos Artísticos Timorenses e sua reintegração (1987) (Timorese Art Motifs and its Reintegration) is to 
create a repertoire, which would permit to crystalize this heritage for guiding "future artisans," the Timorese young people. Also the newspaper $A$ voz de Timor (The Voice of Timor) seems to have played an important role in stimulating and conceiving fields of artistic production in and about East Timor, through the publication of poetry, short stories, as well as "local curiosities." In this sense, the facsimile reproduced in figure 1 is an important historical testimony. Among other works, those of João Soariano, who studied drawing with Ruy Cinatti, are outstanding (Viegas, this volume).

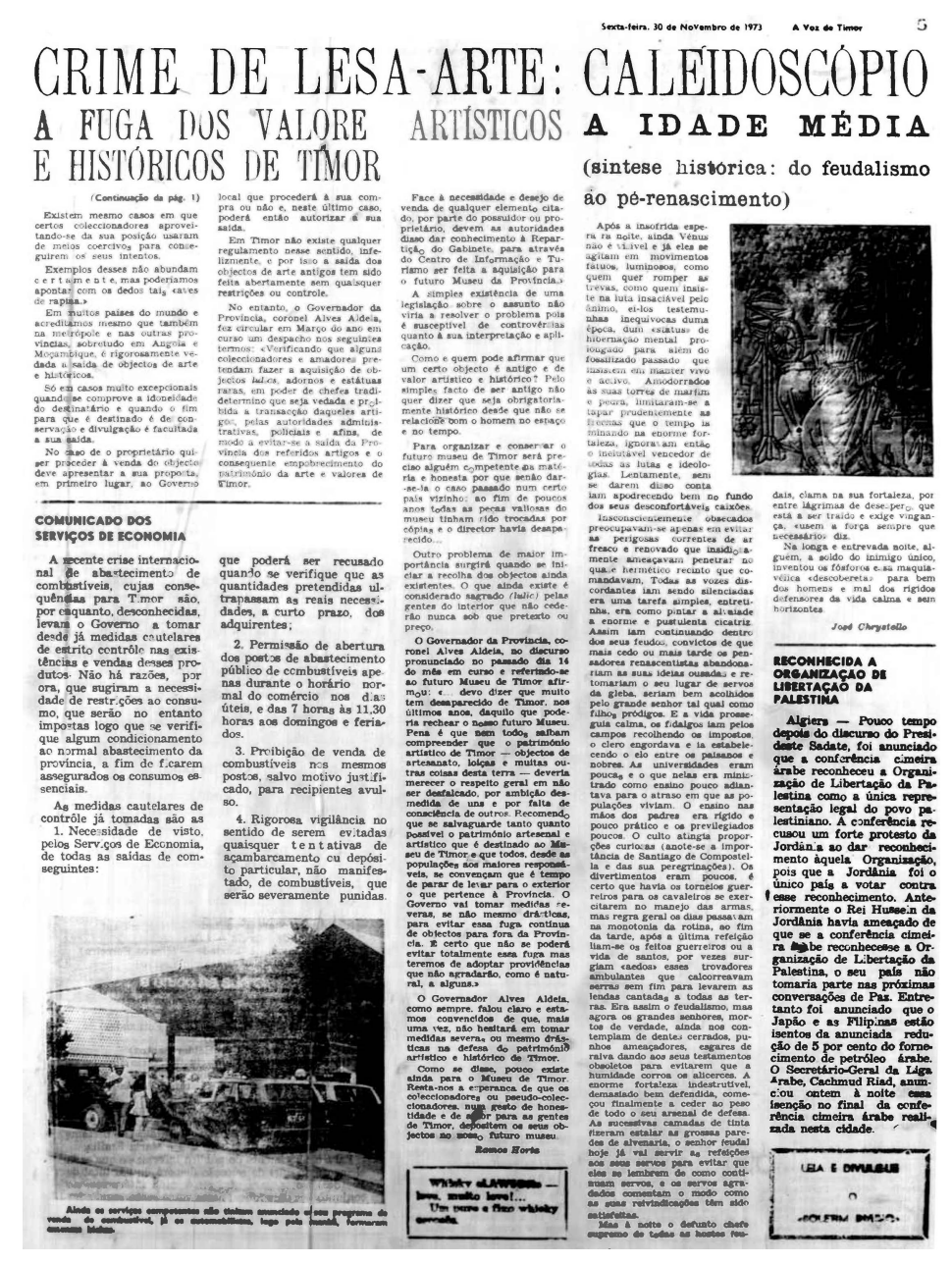

Figure 3

A common element seems to level out the perception of Timorese art through time, namely, the close relation of crafts and artifacts to native life. However, we know that there has been an appropriation of these artifacts, elected as indigenous or popular art expressions, for a metropolitan or tourist public. This appropriation results from the official support of mass production, sometimes "imitating" other models. With the passage of time, native art has gained the appreciation of outside markets and become the object of legal, and often illegal, demand. Ruy Cinatti stated his concern in a 1973 confidential letter where he expressed his worries about the usurpation of these goods at the risk of leaving only "disinherited" people in Timor. ${ }^{12}$ Such a concern also appeared in the newspaper $A$ Voz do Timor (The Voice of Timor) in an

12 Ruy Cinatti's Estate, Library of the Catholic University, Lisbon. Arquivador Terminus Timor's D XI: Confidential information - Cultural Heritage: historical, artistic, and ethnographic of Timor. 3.10.1973. 5 fls. 
article by Ramos Horta, published on November 30, 1973, titled Crime de Lesa-Arte. A fuga de valores artisticos e históricos de Timor (Crime of 'lese art.'The plunder of Timor's artistic and historical treasures, see figure 2 and 3 ).

The period of Indonesian occupation seems to confirm Cinatti's fears. Here and there, reports of indigenous pieces taken to Bali for sale testify to that chaotic period. At the same time, as occupation settles in, comes the need to legitimize integration. Among the actions taken was the use of Timorese artistic manifestations in public acts of recognition. Viegas (this volume) shows the consolidation, at that time, of the production of Timorese art in prisons and in the Diaspora. During the occupation, a museum was opened in Dili. By September 1999, little remained of it. Now, the building has become the headquarters of the Arte Moris School.

\section{From the nationalization of the arts to the production of new Orientalisms}

The appropriation of certain cultural expressions as national art is typical of nation-building processes. To a certain extent, it is always relational, because it takes into consideration the expectations of those who are in and out the national space. ${ }^{13}$

The quest for the return of an imagined origin that would stand as the essence of national identity is part of government cultural policies, both national and international, for the reconstruction of the sacred houses (Uma lulik in Tétum) in East Timor. Similarly to what Acciaioli (1985) had pointed out for Indonesia in the 1980s, Fidalgo-Castro (this volume) shows how these policies involve the esthetization of culture. Moreover, this author analyzes the tensions and conflicts that these policies may trigger off, given the power effect they have on local and national scenarios.

We can also see State funding of street art in East Timor as part of the issue of national construction. Unlike what occurs in other countries, Arthur (this volume) indicates the dependence of Timor street art on State financing. Among other things, this leads to the use of street art as an instrument of pacification, for it conveys messages of unity in contexts of conflict or post-conflict.

Relational and contrasting elements found in the dynamics of individual and collective subjectivation are also a theme in Viegas and Soares articles in this volume. In the case of visual arts, Viegas discusses in what ways the use of "fragments of tradition" by artists of Movimento Kultura responds to a double demand. On the one hand, it relates to the esthetic expectations of the market that consumes the art they produce. This market includes mostly foreigners who seek pieces whose symbols should be typically East Timorese, such as tais, belak (golden disc), kaiobau, etc. We can thus say that Movimento Kultura, at least in part, is hostage to a certain Orientalism, to the extent that it feeds the consuming demands of those who can acquire Timorese art pieces. On the other hand, in their work the artists make their use of "tradition" meaningful as a way to publicize Timorese identity. Following a trend similar to that which Leach (2012) identifies among Dili university students, artists of the movimento kultura state

13 We follow Said's (1996) provocative idea about the invention of an Orient based on reasons and interests of the Occident. 
that being Timorese is closely tied to connectedness to, knowledge of, and respect for tradition. Maria Madeira, a senior member of Movimento Kultura and one of the most prestigious East Timorese visual artist both at home and abroad, adds new reasons for the use of fragments of tradition in her work. Her purpose is to know her own origins better - she was raised and trained in Australia - and to empower women who retain some of the knowledge related to her métier. In Arthur's article, we also see how the word kultura is deployed to attain pacification.

Our appraisal of Viegas' article is inspired by the profound and provocative text by Antony Soares in this volume. Based on a comparative reading of Paulo Braga's colonial work and the critique of Luis Cardoso's oeuvre, Soares shows how Orientalism is present in both. He then proposes that certain literary narratives of enchantment and disenchantment, colonial and postcolonial about East Timor are expressions of a narcissistic projection in which the territory and its peoples appear as desires and frustrations made true by those who produce and consume such works. Thus, in Paulo Braga's narratives and in part of the interpretations of Luis Cardoso's work, East Timoreses (or the Lusophones) become icons of resistance to Anglophone Western domination, impossible to come about in the Metropolis. Such narratives, Soares suggests, silence past and present genealogies of capitalist interests and exploitation, in the name of a narcissistic projection. Allow us to reproduce here a passage of his texts.

\begin{abstract}
What I would like to suggest by way of a conclusion is that there is a risk that critical readings of contemporary East Timorese literature may embed exoticised notions of Timor-Leste that belong to what Alós terms the 'imaginário pós-colonial lusófono' (141). This 'Lusophone postcolonial imaginary' will travel to a Timor-Leste that is a fiction in order to fight the hegemonic forces that emanate from elsewhere, finding a Lusophone difference - an exceptionality - to raise as a banner of defiance against a 'West' that is perhaps unfairly characterised as essentially Anglophone, and whose precise limits are rarely made explicit. In this act, readers (Portuguese?) in the 'West' turn the pages of an East Timorese (Angolan, Mozambican) novel and are comforted by evidence of a post-Lusotropical-like identity that points to the survival of a way of being in the world seemingly under threat.
\end{abstract}

Furthermore, it is interesting to ask to what extent Orientalist expectations have imposed themselves in other artistic production of and about East Timor, and the ways this production has responded to the historical and social contingencies experienced by the national and international elites who have produced and consumed them.

\title{
For ETHNOGRAPHIES OF the MEdiations IN THE MAKING OF EAST TIMOR ART WORLDS
}

In the wake of what anthropology and sociology have long been showing, we stated above that the recognition of some manifestation, as art, is a social process. It comprises various kinds of mediation that include the development of taste, dialogue with consumer market, negotiation of artistic languages, institutional mediations, etc. In this section, we would like to indicate some of the institutional actors and phenomena that seem to play an important role in contemporary processes of making East Timorese art worlds. These deserve analytical attention in investigations on the theme.

Just as occurred in the colonial period, the State is a fundamental actor in the dynamics of negotiation and conflict related to the emergence and consolidation of East Timorese art worlds. Since the State is the major investor in the country, the ways in which it invests human, financial and technological resources in culture and art will play an essential role in the making 
of art fields. Good examples of these initiatives are those carried out by the Secretary of Art and Culture, part of the Ministry of Tourism. Among these are the granting of scholarships, policies of recognition, recovery and protection of (material and immaterial) cultural goods, promotion of exhibitions, creation of museums and the Academia Nacional de Artes e Induistrias Culturais Criativas (National Academy of Arts and Creative Cultural Industries). ${ }^{14}$

The 2012 transfer of today's Secretary of Art and Culture from the Ministry of Education to the Ministry of Tourism indicates the role tourism plays now and may play in the future in the consolidation of East Timor's art fields, responding to a global trend reproduced in various places. ${ }^{15}$ Morphy (2005: 677) states very clearly some of the implications of the relations between tourism and art:

Through tourism, films, exhibitions, cultural festivals and the sale of craft products, art has increasingly been inserted into the space between indigenous people and the developed word. It provides an area of interaction and of value exchange, a means of asserting cultural identity, and, increasingly, a context for political action through copyright and cultural heritage legislation.

We must remember then that the State in East Timor and elsewhere does not act in isolation or in full autonomy. From a certain point of view, East Timorese national State operates as a mediator in implementing cultural policies, transnationally negotiated by entities such as UNESCO. From another perspective, when expertise is insufficient, local and transnational civil society organizations also support Timorese art and culture. We mention the important contribution of the Tatoli ba Kultura (The Way to Culture) project ${ }^{16}$. It has recorded and, whenever possible, catalogued cultural goods and expressions in East Timor with the purpose of preserving or promoting them in the Academia Nacional de Artes e Induistrias Culturais Criativas (National Academy of Arts and Creative Cultures Industries). Otherwise, the Arte Moris project, school and museum have been crucial to reconstruct and consolidate art fields in the country. They gave rise to other artistic collectivities, such as Gembel, portrayed in Angie Bexley's article (this volume). Initiatives like the Ramelau and Arte Publiku festivals, among others, have been relevant in the social construction of art fields. ${ }^{17}$ It is important to point out that most of these events are financed by international cooperation for development, which, as in other fields of social action in the country, continues to play an exceptional role in the processes of transposition, invention, and subversion of modernity in East Timor (Silva 2012).

We should also emphasize the importance of institutions that have funded or sponsored the production of artistic works about East Timor, including those abroad, such as the Espaço e Biblioteca Por Timor (Space and Library for Timor), maintained by the Municipal Chamber of Lisbon, where it is placed. The strategic use of culture or of what was regarded as Timorese art was an important tactic of resistance to Indonesian occupation, mainly by East Timor people in exile or in Diaspora in Portugal, Macau, and Australia. The presentation of tebedai choreographies, traditional chants, paintings portraying local conditions of social reproduction were channels for the mobilization of international public opinion and support for the restauration of Independence in the country. In these contexts, the Timorese presented their art and culture as violated by Indonesian military occupation (Viegas 1998, Miranda 2003, Tique 2013).

14 About past and present practices of the Secretary of Art and Culture, see: http://www.cultura.gov.tl/ 15 For an analysis of the ways in which culture has been handled with the purpose of promotion of tourism in East Timor in the colonial and post-colonial periods, see Oliveira (2013).

16 For further information about this project, see www.tatolibakultura.org

17 For more information on the Arte Públiku Festival, see: http://dilifestival.com/about/ 
Maria Madeira's trajectory, discussed in this volume by Leonor Viegas, is an example. We could cite other artists who produced in Diasporic conditions, such as Leopoldino Lobato Soriano, Sebastião Silva, Tchum Nhu Lien, Fátima Guterrez, and Abel Júpter T. Freitas da Silva.

Analyses of knowledge, meanings, and the effects of tais (ikat) making, as well as pottery, music, and dance among East Timor peoples seem to be highly promising for the development of the anthropology of art in and about Timor. Of the initiatives available, we highlight the work of Dunlop (2012), Yampolsky (2014), and Galipaud and Assis (2014).

We end by thanking the participants in this work. They represent the cosmopolitan collection of researchers who, one way or the other, are close to East Timor. We thank them and those who, for several reasons, could not be included in this enterprise.

A word of praise goes to all the reviewers for their diligent evaluation of the articles and excellent suggestions. Lastly, our thanks to the editors for their courage to feature this theme in the Journal and for all the work involved in this process.

\section{Biblography}

Acciaioli, Greg. 1985. "Culture as Art: From Practice to Spectacle in Indonesia." Canberra Anthropology 8 (1 \& 2):148-72

Almeida, António. 1994. O Oriente de Expressão Portuguesa. Lisboa: Fundação Oriente/Centro de Estudos Orientais.

Bordieu, Pierre.1983.” Algumas propiedades dos campos”. In: Pierre Bourdieu. Questões de Sociologia. Rio de Janeiro: Editora Marco Zero Limitada.

.1996. As regras da arte - gênese e estrutura do campo literário. Rio de Janeiro: Companhia das Letras: 2010. El sentido social del gusto. Buenos Aires: Siglo Veintiuno Editores.

Castro, Afonso. 1867. As Possessões Portuguesas na Oceânia. Lisboa: Imprensa Nacional de Lisboa.

Cinatti, Ruy. 1987. Motivos Artísticos Timorenses e a sua integração. Lisboa: Instituto de Investigação Cientifica Tropical - Museu de Etnologia.

Duarte, Jorge B. 1984. Timor: ritos e mitos ataúros. Lisboa: Instituto de Cultura e Língua Portuguesa.

Dunlop, Ros. 2012. Sounds of the Soul: The Traditional Music of East Timor. Rozelle: Tekee Media Inc.

França, Bento. 1891. Timor. Lisboa: Companhia Nacional Editora.

Fox, James. 1988. "Introduction". In: To Speak in pairs. Essays on the ritual languages of eastern Indonesia, edited by James Fox. Cambridge: Cambridge University Press.

Lagrou, Els. 2009. Arte Indígena no Brasil. Belo Horizonte: Editora Arte.

Layton, Robert. 2001 [1991]. A Antropologia da Arte. Lisboa: Edições 70.

Leach, Michael. 2012. "Longitudinal change in East Timorese tertiary student attitudes to national identity and nation-building: 2002-2010". In Journal of the Humanities and Social Sciences of Southeast Asia and Oceania, 168(2-3): 219 - 252.

Galipaud, Jean-Christophe \& Assis, Celilia. 2014. Sanan Rai. Um patrimônio em extinção em Timor-Leste. Dili: Secretaria de Estado de Arte e Cultura.

Gell, Alfred. 1998. Art and Agency. An anthropological theory. Oxford: Clarendon Press. 
Gomes, Francisco A. 1972. Os Fataluku. Dissertação de licenciatura. Lisboa: ISCSPU.

Keane, Webb. 2007. Christian Moderns: Freedom E' Fetish in the mission encounter. Berkeley: University of California Press.

Latour, Bruno. 1994. Jamais fomos modernos. Rio de Janeiro: Ed. 34.

Menezes, Francisco X.. 2006. Encontro de Culturas em Timor-Leste: contribuição para o seu estudo. Díli: Crocodilo Azul.

Miranda, Sofia. 2003. A Cruz e o Sândalo. Religião, Tradição e Gerações Timorenses. Dissertação de Mestrado. Lisboa: ISCSTE.

Morphy, Howard. 2005 [1994]. "The anthropology of art" in Companion Encyclopedia of Anthropology, edited by Tim Ingold. Londres: Routledge, p. 648-685.

Oliveira, Fabiana S.R.2013. Pluralidade de vozes, sentidos e significados do turismo no Timor-Leste: projetos turísticos e a negociação da cultura leste-timorense. Dissertation for the Degree of Bachelor in Social Sciences, Universidade de Brasília. Available at: <http://bdm.bce.unb. br/bitstream/10483/4796/1/2013_FabianaSantosRodriguesdeOliveira.pdf> .

Pascoal, Ezequiel E. 1967. Alma de Timor Vista na Sua Fantasia. Braga: Barbosa e Xavier Lda..

Rodrigues, José. 1962. O Rei de Nári: histórias, lendas, tradiçôes de Timor e episódios da vida missionária. Lisboa: Agência-Geral do Ultramar.

Sá, Artur B. 1961. Textos em teto da literatura oral timorense. Lisboa: Junta de Investigações do Ultramar, Centro de Estudos Políticos e Sociais.

Said, Edward. 1996. Orientalismo. O Oriente como Invenção do Ocidente. São Paulo: Companhia das Letras.

Silva, Kelly. 2012. As nações desunidas - Práticas da ONU e a estruturação do Estado em TimorLeste. Belo Horizonte: Editora UFMG/Humanitas.

Silverstein, Michael. 2000. "Whorfianism and the linguistic imagination of nationality" in Regimes of languages. Ideologies, Polities and Identities, edited by Paul Kroskrity. Oxford: School of American Research Press.

Sousa, Lúcio. 2010. An tia: partilha ritual e organização social entre os Bunak de Lamak Hitu, Bobonaro, Timor-Leste. Tese de Doutoramento. Lisboa: Universidade Aberta.

Thomaz, Luís F. 2008. País dos belos: achegas para a compreensão de Timor-Leste. S.1.: Instituto Português do Oriente: Fundação Oriente.

Tique, Rosário. 2013. Processos identitários e práticas transnacionais: os timorenses na Austrália. Tese de Doutoramento. Lisboa: Universidade Aberta.

Viegas, Telma. 1998. Migraçóes e associativismo de migrantes: estudo do caso timorense. Lisboa. Universidade Aberta e Fundação Oriente.

Yampolsky, Philip. 2014. Melody in the Duet-Singing of Fataluku-Speakers (East Timor). Retrieved March 3, 2015 (http://aawmconference.com/aawm2014/abstracts/yampolsky\%20abstract.pdf)

\section{Primary SOURCES}

Horta, Ramos. 1973. Crime de Lesa-Arte. A fuga de valores artísticos e históricos de Timor. 30 de Novembro.

João Soriano e Celestino Encarnação. Dois artistas Timorenses. 1973. Jornal A Voz de Timor. 29 June. 